thyroid function tests in such patients are readily resolved by the direct measurement of TBG.

\section{References}

1 Woeber, K A, and Ingbar, S H, fournal of Clinical Investigation, 1968, 47, 1710 .

2 Oppenheimer, J H, New England fournal of Medicine, 1968, 278, 1153.

3 Robbins, J, Archives of Biochemistry and Biophysics, 1956, 63, 461

4 Horn, D B, Fournal of Clinical Pathology, 1975, 28, 218.

5 Clark, F, and Horn, D B, fournal of Clinical Endocrinology and Metabolism, $1965,25,39$.

6 Howorth, P J N, and Maclagen, N F, Lancet, 1969, 1, 224.

7 Wellby, M L, O'Halloran, M W, and Marshall, J, Clinical Endocrinology, $1974,3,63$.

${ }^{8}$ Bold, A M, and Browning, D M, fournal of Clinical Pathology, 1975, 28, 234.

${ }^{9}$ Souma, J A, et al, American fournal of Obstetrics and Gynecology, 1973, 116, 905.

10 Goolden, A W G, Gartside, J M, and Sanderson, C, Lancet, 1967, 1, 12.
${ }^{11}$ Bradwell, A R, et al, Clinica Chimica Acta, 1976, 71, 501.

${ }^{12}$ Levy, R P, Marshall, J S, and Velayo, N L, fournal of Clinical Endocrinology and Metabolism, 1971, 32, 372.

13 Cavalieri, R R, McMahon, F A, and Castle, J N, fournal of Clinical Investigation, 1975, 56, 79.

14 Hesch, R-D, et al, Clinica Chimica Acta, 1976, 70, 33.

15 Gershengorn, M C, Larsen, P R, and Robbins, J, fournal of Clinical Endocrinology and Metabolism, 1976, 42, 907.

16 Clark, F, and Brown, H J, British Medical fournal, 1970, 1, 713.

17 Burr, W A. Unpublished observations.

18 Laurell, C B, Analytical Biochemistry, 1966, 15, 45.

19 Ratcliffe, W A, et al, Clinical Endocrinology, 1974, 1, 481.

20 Inada, $M$, and Sterling, K, Fournal of Clinical Investigation $1967,46,1442$.

${ }^{21}$ Hesch, R-D, et al, European fournal of Clinical Investigation, 1976, 6, 139.

${ }^{22}$ Jones, J E, and Seal, U S, fournal of Clinical Endocrinology and Metabolism, 1967, 27, 1521.

23 Siersbaek-Nielsen, K, Hansen, J M, and Hippe, E, Acta Endocrinologica ڤొ (Kobenhavn), 1969, 60, 130

${ }^{24}$ Hodgson, S F, and Wahner, H W, Mayo Clinic Proceedings, 1972, 47, 720.

${ }^{25}$ Harvey, R F, Lancet, 1971, 2, 230.

\title{
Effect of eating liquorice on the renin-angiotensin aldosterone axis in normal subjects
}

\author{
M T EPSTEIN, E A ESPINER, R A DONALD, H HUGHES
}

British Medical fournal, 1977, 1, 488-490

\section{Summary}

The effect of confectionery liquorice on electrolyte status and the renin-angiotensin-aldosterone (RAA) axis was studied in 14 healthy volunteers. They ate liquorice in daily doses of $100 \mathrm{~g}$ or $200 \mathrm{~g}$ (equivalent to 0.7-1.4 g glycyrrhizinic acid) for one to four weeks.

Plasma potassium concentrations fell by over 0.3 $\mathrm{mmol} / \mathbf{1}$ in 11 people, including four who had to be withdrawn from the study because of hypokalaemia. One or more values of the RAA axis, especially plasma renin activity and urinary aldosterone concentrations, were considerably depressed in all subjects. These results show that potentially serious metabolic effects may occur in some people who eat modest amounts of liquorice daily for less than a week.

\section{Introduction}

The syndrome of pseudo-primary aldosteronism is a well-known complication of chronic liquorice ingestion. ${ }^{1-4}$ Glycyrrhizinic acid, the active component of liquorice, has mineralocorticoid effects on electrolyte balance in normal people when taken in high doses (4-6 g), ${ }^{5}$ but the extent to which liquorice as sweets affects the electrolyte balance and the renin-angiotensinaldosterone (RAA) axis in normal people is not known. Such information is important in view of the amount that liquorice is

\footnotetext{
The Medical Unit, The Princess Margaret Hospital, Christchurch, 2 New Zealand

M T EPSTEIN, MSC, MRCP, endocrine registrar

E A ESPINER, MD, FRACP, endocrinologist

R A DONALD, PHD, FRACP, endocrinologist

H HUGHES, PHD, senior biochemist
}

eaten in the community and the serious nature of chronic. ㄱ. liquorice intoxication. We have attempted to answer some of $\square$ these questions.

\section{Subjects and methods}

Fourteen volunteers were studied. There were nine women aged 19 to 40 years and five men aged 21 to 46 years. None weighed more than $15^{\circ}$ above ideal body weight. All subjects were normotensive and none had taken any medication, oral contraceptives, or liquorice in the preceding month. All subjects were studied when eating their usual home diets. Five men and four women ate $100 \mathrm{~g}$ of liquorice (two confectionery twists) daily and five women ate $200 \mathrm{~g}$ (four confectionery twists) daily for one to four weeks. Subjects were examined before the study, each week during it, and one (13 subjects) and two (11 subjects) weeks after liquorice was withdrawn. At each assessment lying and standing blood pressure and body weight were measured. Blood was drawn at 10 am for measurement of plasma aldosterone, 음 plasma renin activity (PRA), plasma angiotensin II, and plasma $N$ electrolytes. On the same day a 24 -hour urine collection for determining aldosterone, sodium, and potassium concentrations was taken. $\frac{D}{2}$

PRA, angiotensin II, and aldosterone were measured by radioimmunoassay. ${ }^{6-9}$ All samples from a single subject were measured in $\mathrm{N}$ the same assay, and when possible several subjects' samples were N్ included in the same assay.

\section{Results}

Eight subjects (five men and three women) completed four weeks of liquorice ingestion. Liquorice was prematurely withdrawn from six women because of either hypokalaemia (in four) or uncomfortable oedema of the face, hands, and ankles (in two). Another four people (one man and three women developed mild transient generalised $\widetilde{\sigma}$ oedema. Other side effects were headache in three subjects and $?$ lethargy in four. Blood pressure did not rise significantly in any음 subject. Ten people suffered a weight gain greater than $1 \mathrm{~kg}$, and the two subjects with the most pronounced oedema gained $2.3 \mathrm{~kg}$ and $\frac{0}{\partial}$ $4 \mathrm{~kg}$ in one and three weeks. The mean weight gain for the whole? group was $1.5 \pm(\mathrm{SD}) 0.7 \mathrm{~kg}$. In all cases weight returned to control levels within one week of liquorice withdrawal.

Electrolyte imbalance was shown in most subjects on both dose 
schedules. In 12 subjects plasma potassium concentrations fell by up to $1.5 \mathrm{mmol}(\mathrm{mEq}) / \mathrm{l}$, and subnormal levels were seen in five subjects (fig 1). In four of these five subjects plasma potassium fell within the first week of liquorice ingestion. Concentrations returned to normal in all except one subject a week after liquorice was withdrawn. Although the main electrolyte changes were noted in potassium, plasma sodium concentrations also tended to rise during liquorice ingestion, and after liquorice withdrawal a sodium diuresis was observed in most subjects. These latter changes did not, however, reach significance statistically.

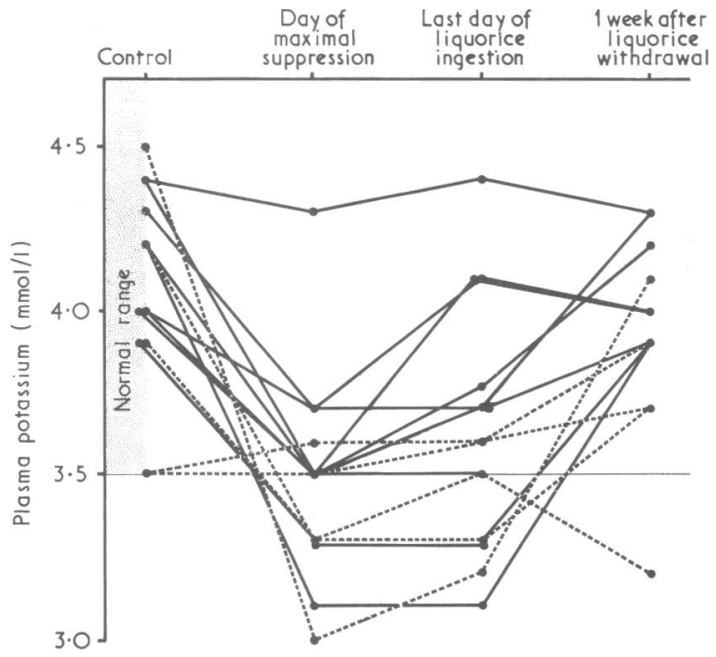

FIG 1-Plasma potassium concentrations in individual subjects before, during, and after liquorice ingestion. Solid lines represent subjects taking $100-\mathrm{g}$ dose and dotted lines subjects on $200-\mathrm{g}$ dose.

There was obvious suppression of one or more values of the RAA axis in all subjects on both dose schedules (see table). This suppression was generally noted by the first week. Plasma renin activity fell to less than half the control value in 13 of the 14 subjects, and in 10 subjects subnormal levels were seen (fig 2). PRA levels in eight of these 10 subjects were either very low or non-detectable (0-0.15 $\mathrm{nmol} / \mathrm{l} / \mathrm{h}(0-0 \cdot 2 \mathrm{ng} / \mathrm{ml} / \mathrm{h}))$. In all except one subject urinary aldosterone fell into the subnormal range, and in four, levels were undetectable (fig 2). Plasma aldosterone levels fell by more than half in 12 subjects but only two subjects showed subnormal levels. Plasma angiotensin II levels fell by more than a third in 11 subjects, but only three of these subjects showed subnormal levels.

One man in whom all values of the RAA axis were initially suppressed later showed normal values despite continued liquorice ingestion. He showed no significant fall in plasma potassium concentrations. In the remaining subjects RAA axis suppression continued during liquorice ingestion, although signs of recovery were observed in some subjects (see fig 2). Despite this tendency, PRA, plasma angiotensin II, and urinary aldosterone concentrations remained subnormal in five, two, and seven subjects respectively one week after liquorice was withdrawn. Urinary aldosterone concentrations (which showed the greatest suppression of the RAA values) were the slowest to recover and remained subnormal in two subjects two weeks after
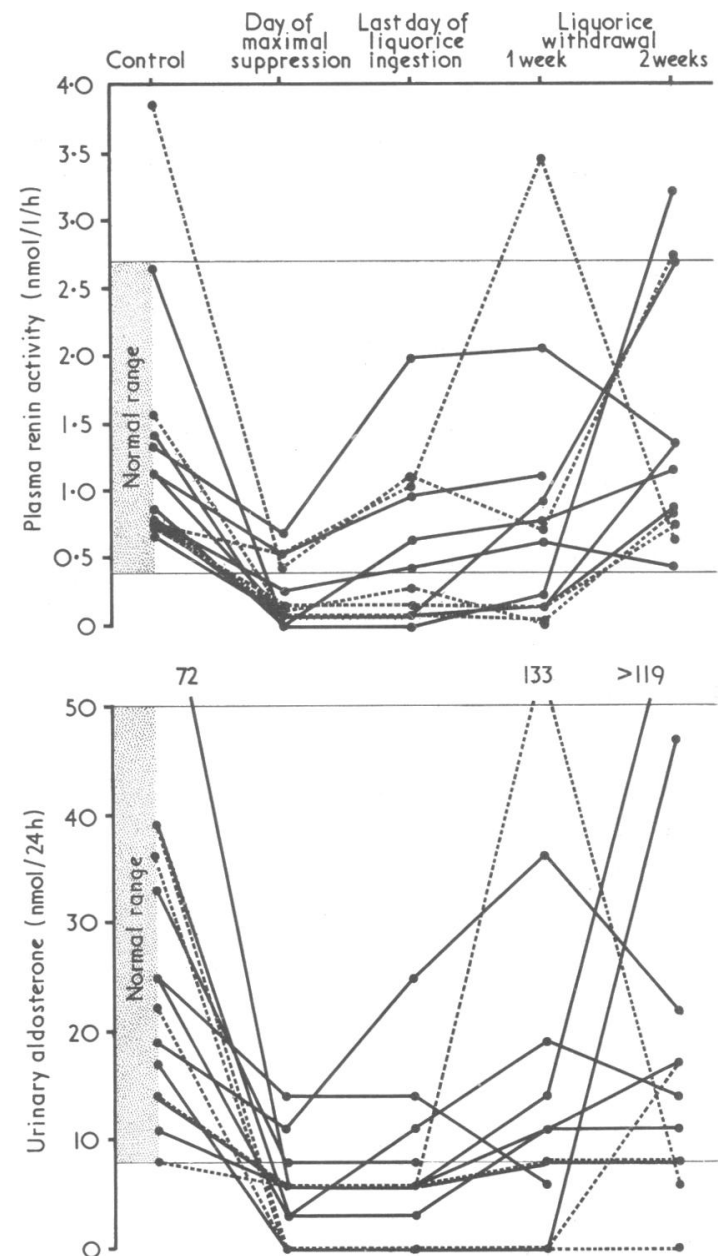

FIG 2-PRA and urinary aldosterone levels in individual subjects before, during, and after liquorice ingestion. Solid lines represent subjects on $100-\mathrm{g}$ dose and dotted lines subjects on $200 \mathrm{~g}$ dose.

Conversion: SI to traditional units-PRA: $1 \mathrm{nmol} / 1 / \mathrm{h} \approx 1.30$ $\mathrm{ng} / \mathrm{ml} / \mathrm{h}$. Urinary aldosterone: $1 \mathrm{nmol} / 24 \mathrm{~h} \approx 0.36 \mu \mathrm{g} / 24 \mathrm{~h}$.

liquorice withdrawal. Subjects with the most prolonged RAA axis suppression were the most severely affected, as judged by the hypokalaemia and oedema that necessitated their premature withdrawal from the study.

\section{Discussion}

Our results indicate that liquorice in doses of 100 or $200 \mathrm{~g} /$ day (two or four confectionery twists) has a considerable, rapid, and sustained mineralocorticoid action in most normal men and women. Reported clinical and electrolyte disturbances in patients fed liquorice were confirmed. ${ }^{1-4}$ The hypokalaemic

\begin{tabular}{|c|c|c|c|c|c|c|c|c|c|c|}
\hline & & & & & & $\begin{array}{c}\text { No of } \\
\text { patients }\end{array}$ & $\begin{array}{c}\text { PRA } \\
(\mathrm{nmol} / \mathrm{l} / \mathrm{h})\end{array}$ & $\underset{(\mathrm{pmol} / \mathrm{l})}{\text { Plasma angiotensin II }}$ & $\begin{array}{c}\text { Plasma aldosterone } \\
(\mathrm{nmol} / \mathrm{l})\end{array}$ & $\begin{array}{l}\text { Urinary aldosterone } \\
(\mathrm{nmol} / 24 \mathrm{~h})\end{array}$ \\
\hline Normal range $\dagger \ldots$ & . & . & . & .. & .. & & $0.38-2.69$ & $19-66 \cdot 5$ & $139-695$ & $8 \cdot 3-50$ \\
\hline \multicolumn{4}{|c|}{$\begin{array}{l}\text { Control week } \\
1 \text { Week after starting liquorice ingestion } \\
\text { Day of maximal hormonal suppression } \\
\text { Last day of liquorice ingestion } \\
1 \text { Week after liquorice withdrawal } \\
2 \text { Weeks after liquorice withdrawal }\end{array}$} & $\begin{array}{l}\cdots \\
\because \\
\cdots \\
\cdots\end{array}$ & $\begin{array}{l}. . \\
\because \\
\because \\
\cdots \\
.\end{array}$ & $\begin{array}{l}14 \\
14 \\
14 \\
14 \\
13 \\
11\end{array}$ & $\begin{array}{c}1.32 \pm 0.9 \\
0.64 \pm 0.6 \\
0.2 \pm 0.23^{* *} \\
0.5 \pm 0.58 \\
0.79 \pm 0.99 \\
1.45 \pm 0.96\end{array}$ & $\begin{array}{c}52 \pm 21 \\
40 \cdot 2 \pm 13 \cdot 9 \\
30 \pm 14^{*} \\
39 \pm 21 \\
40 \pm 11 \\
52 \pm 20\end{array}$ & $\begin{array}{l}598 \pm 433 \\
197 \pm 52 \\
167 \pm 44 * * \\
239 \pm 117 \\
373 \pm 222 \\
587 \pm 467\end{array}$ & $\begin{array}{c}27 \pm 17 \\
13 \cdot 3 \pm 16 \cdot 7 \\
5 \pm 4^{* *} \\
7 \pm 6 \cdot 5 \\
20 \pm 3 \cdot 7 \\
24.5 \pm 34\end{array}$ \\
\hline
\end{tabular}

+ Normal range, obtained from 74 normal volunteers at 10 am when they were upright.
Significant difference from control value (Dunnett test ${ }^{10}$ ): $* P<0 \cdot 05 ; * * P<0 \cdot 01$. Only values on control day, day of maximal suppression, and one week after liquorice withSignificant difference fromal were compared.

Conversion: SI to traditional units_-PRA: $1 \mathrm{nmol} / \mathrm{l} / \mathrm{h} \approx 1.30 \mathrm{ng} / \mathrm{ml} / \mathrm{h}$. Plasma angiotensin II: $1 \mathrm{pmol} / 1 \approx 1 \cdot 05 \mathrm{pg} / \mathrm{ml}$. Plasma aldosterone: $1 \mathrm{pmol} / 1 \approx 0 \cdot 036 \mathrm{ng} / 100 \mathrm{ml}$. Urinary aldosterone: $1 \mathrm{nmol} / 1 \approx 0.36 \mu \mathrm{g} / 24 \mathrm{~h}$ 
effect was particularly pronounced, and sodium retention, with concommitant weight gain, was also evident. These effects appeared, however, at much lower doses (0.7-1.4 g glycyrrhizinic acid) than those used in other studies (4-9 g).$^{1-4}$

Both doses in this study seemed to be equipotent in causing electrolyte and RAA axis disturbance, but the higher dose caused the most rapid changes. Some volunteers had considerable suppression of the RAA axis and no obvious electrolyte imbalance, but presumably electrolyte imbalance would occur eventually. Of the RAA axis values studied, both PRA and urinary aldosterone concentrations seemed to be the worse affected and to the same degree. Subnormal levels indistinguishable from those seen in Conn's syndrome were the rule. Plasma angiotensin II and plasma aldosterone were léss discriminatory and their measurement alone would not single out the liquorice eater from others. One subject clearly suppressed all three RAA axis values after one week, gained $1.4 \mathrm{~kg}$ in weight, developed oedema of the ankles, but then returned to normal by the next week despite continued liquorice ingestion. He adapted in some way to the liquorice compound, presumably by altered absorption or degradation. Whatever the adaptation mechanism might be, however, our results suggest that such people represent a small minority and that potentially serious metabolic effects will occur in people consuming moderate daily doses of liquorice for periods as short as one week. Nearly all subjects will be affected within one month.

We can only speculate about the effect of smaller daily doses or larger less regular doses, but it would seem prudent to advise patients with hypertension or other circulatory disorders to abstain completely and for others to be made aware of its potential toxicity.
In all but the most severely affected subjects hormonal values quickly returned to normal once liquorice was withdrawn. We therefore presume that many cases of liquorice toxicity go unrecognised, particularly after admission to hospital, where the source of the problem is removed.

We thank our volunteers for participating in this study. We acknowledge with thanks the help of Daphne Hinton, Kay Miles, and Corrine Roberts for the electrolyte and radioimmunoassay work performed. We thank A \& B Consolidated Limited for co-operation in supplying the liquorice. Antialdosterone serum was supplied by the National Institutes of Health, Bethesda, Maryland, USA. This work was supported in part by a grant from the Medical Research Foundation of New Zealand.

\section{References}

1 Groen, J, et al, New England fournal of Medicine, 1951, 244, 471.

2 Groen, J, et al, fournal of Clinical Investigation, 1952, 31, 87.

${ }^{3}$ Carb, W I, et al, Lancet, 1953, 1, 663.

${ }^{4}$ Louis, L, and Conn, J W, Fournal of Laboratory and Clinical Medicine, 1966, 47, 20.

5 Conn, J W, Rovner, D R, and Cohen, E L, Fournal of the American Medical Association, 1968, 205, 80.

${ }^{6}$ Haber, E, et al, fournal of Clinical Endocrinology and Metabolism, 1969, 29, 1349.

' Ito, T, et al, Fournal of Clinical Endocrinology and Metabolism, 1972, 34, 106.

${ }^{8}$ Nicholls, M G, and Espiner, E A, New Zealand Medical fournal, 1975, 81, 490.

9 Nicholls, M G, et al, Clinical Science and Molecular Medicine, 1974, 47, 301.

10 Dunnett, C W, American Statistical Society fournal, 1955, 50, 1096.

(Accepted 22 December 1976)

\section{SHORT REPORTS}

\section{Toxoplasmosis and erythema nodosum}

Erythema nodosum is characterised by a red, nodular skin eruption that is classically described as occurring on the shins. Traditionally it has been associated with diseases such as streptococcal infections, sarcoidosis, and, in days gone by, tuberculosis. ${ }^{1}$ Viral infections, pasteurella infections, and coccidioidomycosis have also been implicated. Sulphonamides and the various contraceptive pills have been blamed. A few patients with ulcerative colitis and malignant disease have erythema nodosum. Recently erythema nodosum has been found in patients with leptospirosis ${ }^{2}$ and brucellosis. ${ }^{3}$ On the other hand, no cause for erythema nodosum can be found in many cases, the percentage of cases varying in different series from $9-30^{\circ}{ }_{0} .^{1}$

I describe here the clinical features of two women who presented with erythema nodosum and who were subsequently found to have toxoplasmosis. One of these cases has already been noted. ${ }^{4}$ No mention of this association has been made in reports of either toxoplasmosis; or erythema nodosum. ${ }^{1}$

\section{Case reports}

Case 1-A 32-year-old woman presented in September with typical erythema nodosum - that is, several small, tender, red nodules on both shins. She complained of aches in various joints and extreme tiredness. Her haemoglobin was $10.4 \mathrm{~g} / \mathrm{dl}$, white cell count $8.0 \times 10^{9} / 1\left(8000 / \mathrm{mm}^{3}\right)$, and erythrocyte sedimentation rate $21 \mathrm{~mm}$ in the first hour. $X$-ray examination of her chest showed bilateral enlarged hilar nodes. Initially sarcoidosis was diagnosed, but the results of the Sabin-Feldman dye test for toxoplasmosis was positive with a titre of $1 / 8192$. Test results for brucellosis were weakly positive: the result of the standard agglutination test was negative, antihuman globulin test gave a titre of $1 / 160$, and complement fixation a titre of
18 , indicative of old infection only. This case seemed similar to the "bilateral hilar lymphadenopathy syndrome" described by Rook. ${ }^{1}$

Case 2-A 33-year-old woman presented in December with several large, tender, red, nodular patches. Uncharacteristically these lesions were found on both buttocks and took several months to subside. She also complained of being tired and of a painful left elbow. Her haemoglobin was $12.8 \mathrm{~g} / \mathrm{dl}$, white cell count $8 \cdot 0 \cdot 10^{9} / 1 \times\left(8000 / \mathrm{mm}^{3}\right)$, and erythrocyte sedimentation rate $2 \mathrm{~mm}$ in the first hour. She had no lymphadenopathy and an $x$-ray picture of her chest was normal. The result of the Sabin-Feldman dye test was positive $1 / 1024$. Toxoplasma-specific IgM was detected at $1 / 32$ by immunofluorescence. Results of brucellosis tests were negative.

\section{Comment}

Both women are married to dairy workers, and live on farms. Both work with the cows alongside their husbands in the byres, and naturally come in contact with other animals such as cats, dogs, and sheep. The second patient in particular emphasised that she made a point of feeding and looking after the numerous farm cats. ${ }^{4}$

\footnotetext{
${ }^{1}$ Textbook of Dermatology, ed A J Rook, D S Wilkinson, and J G Ebling, 2nd edn, Vol I. Oxford, Blackwell, 1972.

2 Goldstein, R S, British Medical fournal, 1976, 1, 809.

${ }^{3}$ Derham, R L J, et al, British Medical fournal, 1976, 2, 403.

4 Longmore, H J A, British Medical fournal, 1975, 1, 94.

${ }^{5}$ Beattie, C P, Toxoplasmosis, Lister Fellowship Lecture, no 28. Royal College of Physicians of Edinburgh, 1964.
}

(Accepted 3 November 1976)

Lochmaben, Dumfriesshire DG11 1NH

H J A LONGMORE, MRCGP, DOBSTRCOG, general practitioner 